\title{
Cardiovascular risk in rural workers and its relation with body mass index
}

Joana Carolina Bernhard', Kely Lisandra Dummel', Éboni Reuter', Miriam Beatris Reckziegel', Hildegard Hedwig Pohl'

\begin{abstract}
Objective: Evaluate the propensity of cardiovascular risk in rural workers and, through the Framingham Risk Score (FRS), relate this risk with the classification of Body Mass Index (BMI). Subjects and methods: This study is characterized as descriptive and exploratory, with the participation of 138 subjects, ranging between 25-73 years old. Clinical and laboratory analysis of the risk factors contained in the FRS were performed, in addition to the determination of BMI, blood pressure, smoking and physical inactivity. Results: The procedures indicated a low risk of a coronary event in 10 years with $70.3 \%$ of the population. In contrast, $88.4 \%$ of the subjects were overweight. It was evidenced a risk improvement as the BMI increased, since $96.4 \%$ of high-risk cases were overweight or obese. Conclusion: Results suggest larger prevalence of intermediary or high FRS for women with higher BMI, which was not observed in men. Arch Endocrinol Metab. 2018;62(1):65-71
\end{abstract}

Keywords

Agribusiness; mortality; cardiovascular diseases
1 Departamento de Educação Física e Saúde, Universidade de Santa Cruz do Sul (Unisc), Santa Cruz do Sul, RS, Brasil

Correspondence to:

Hildegard Hedwig Pohl

Av. Independência, 2293

96815-900 - Santa Cruz do Sul,

RS, Brasil

hpohl@unisc.br

Received on July/3/2016

Accepted on June/6/2017

DOI: 10.20945/2359-3997000000011

\section{INTRODUCTION}

$\mathrm{C}$ ardiovascular diseases are responsible for the high number of deaths, and recorded worldwide data in 2011 of 17 million, since 2000 leading the ranking of the ten leading causes of mortality. Mortality and morbidity levels in adults from 2008 to 2011, reported by WHO, show a significant increase of deaths due to cardiovascular disease, with production losses, and expenses with medical care, treatment and rehabilitation. Predictions are that by 2025 the risk of coronary heart disease and stroke will have increased by $120 \%$ for women and $137 \%$ for men living in developed countries (1). These figures reinforce the importance of effective primary measures for the prevention of these diseases (2).

Hypertension, diabetes mellitus, dyslipidemia, obesity and some habits related to lifestyle (poor diet, smoking, alcohol consumption, physical inactivity) are factors that predispose to cardiovascular risk (3). The Brazilian Society of Cardiology data indicate that $80 \%$ of individuals of the Brazilian adult population is sedentary and $52 \%$ are overweight, $11 \%$ obese, which reinforces the propensity of increased morbidity and mortality, since obesity is an independent risk factor associated with cardiovascular diseases (4).
These aspects combined with regional characteristics of the population and the changes processed in the labor world, with numerous effects on health and epidemiological profile of the working population (5), broaden the spectrum of health problems. Because, in addition to unhealthy lifestyles, inadequate working conditions, such as long working hours and high occupational stress, may predispose workers to high risk of cardiovascular diseases (6).

Rural workers have presented health problems. There is evidence that, by underreporting, the prevalence of diseases is higher in rural than in urban areas. Many factors could be related to health worsening, including restricted access to health system and work economic dependence, which subjects workers to long working days, frequent physical efforts, low income, assiduity even at physical adversities, and long term labor (increasing age group for this population) (7). For the International Labour Organization (ILO) rural work is of great significance, and more dangerous than other activities. It is estimated that millions of farmers suffer from serious health problems (8). Therefore, prevention measures are an important issue in promoting the health of these workers.

Given the complexity of these interactions, it is performed, in 1960, the first cohort study focusing 
on cardiovascular disease by identifying risk factors and pathophysiology, the Framingham Heart Study (FHS), a time when mortality and the incidence of cardiovascular disease showed progressive increases (9). As a result of advances in the FHS, which occurred from 1998, it is possible to stratify the risk of coronary events in 10 years, through a specific score for each risk factor, using clinical variables of daily practice. This indicative stratification of cardiovascular disease risk propensity is classified as low, intermediate and high risk (10). According to the Ministry of Health, the Framingham Score identifies the potential for developing cardiovascular disease even before the onset of symptoms (11).

In this context, the objective of this study is to evaluate the cardiovascular risk in farmers and their relation to the classification of Body Mass Index.

\section{SUBJECTS AND METHODS}

This is a descriptive exploratory study, developed from the database project "Screening of risk factors related to overweight in agribusiness workers using new analytical and health information technologies" developed at the University of Santa Cruz do Sul, approved by the Ethics Committee in Research with Human Beings, under the Protocol 2509/10. We evaluated 138 subjects with a mean age of 51.32 years (SD 10.32), who met the following inclusion criteria: be 18 years old and not be carriers coronary artery disease, stroke, heart failure and acute myocardial infarction.

Labor activities of the sample individuals are those typical of family farming workers, such as planting, farming maintenance, harvesting, animal husbandry, manufacturing of homemade products and trading of the production. Sample was obtained among residents in the municipalities of Santa Cruz do Sul, Passo do Sobrado, Vale Verde, Rio Pardo, Candelária, Encruzilhada do Sul e General Câmara, in the State of Rio Grande do Sul, Brazil. According to Bertê and cols. (12), the region has its rural sector dedicated mainly to monoculture, but receives incentives aiming to diversification of production and development of family agroindustry.

The screening of the subjects was performed by external seminar with the institutions involved in the study. Opportunity in which voluntary participants were informed about the purpose of the study and the conditions of involvement, when the lifestyle questionnaire was applied. Sampling was nonprobabilistic and by convenience.

A survey form proposed by the Brazilian Association of Survey Companies (ABEP - 2014) (13) was used for economic classification, which consists on collecting data of movable and immovable property, domiciliary goods, as well as the graduation level of the householder. There are eight classification levels for Brazilian Criterion: A1, A2, B1, B2, C1, C2, D and E. In this study, subjects were divided in two groups, one of them formed by the members of A1, A2, B1 and $\mathrm{B} 2$, and the other one formed by the remaining categories.

Anthropometric, biochemical and physiological assessments were subsequently applied at the University. The body mass index (BMI) was calculated from the body mass obtained on the scale (Welmy) and height measured in a stadiometer, and calculated from dividing weight $(\mathrm{kg})$ by height $(\mathrm{m})$ squared. Systolic blood pressure (SBP) was measured after five minutes rest, with the subject seated, and the data categorized as normal SBP $(<129 \mathrm{mmHg})$, borderline (between 130 and $139 \mathrm{mmHg}$ ) or hypertension (above 140 $\mathrm{mmHg}$ ) according to the VI Brazilian Guidelines of Hypertension (2010) (14).

Blood tests were performed at the Laboratory of Clinical Biochemistry at the University of Santa Cruz do Sul, using reactive of Labtest brand in semiautomated system (LabMax Progress - LabTest), observing, to the glycemic index the recommendations of the American Diabetes Association (15). Total cholesterol (TC) and high-density lipoprotein cholesterol (HDL-c) reference values of the Brazilian Cardiology Society (16). Blood collection was performed in the brachial vein, preceded by fasting for 12 hours using two vacutainer, one of them containing fluorideloxalate (to obtain plasma) and another without additive (to obtain serum). Blood samples deposited in vacutainer without anticoagulants were incubated at $37^{\circ} \mathrm{C}$ for 15 minutes and centrifuged at $2500 \mathrm{rpm}$ for five minutes to collect serum. The plasma samples were subjected to the determination of glucose (GLU), and the serum samples submitted to the determination of the TC and HDL-c. Diagnosis of diabetes was determined after the results of the glucose test.

According to the criteria proposed by the Framingham Heart Study (FHS) the following risk factors were considered: age, sex, diabetes, TC, HDL-c, smoking and SBP. Through the Framingham score 
(FRS), the risk of occurrence of coronary events in 10 years was calculated. For each risk factor was applied a specific score as suggested by the FHS, obtaining the final score by the sum of individual points. The results were classified as low risk (LR) score $<10 \%$, intermediate risk (IR) score between 10 and $20 \%$ and high risk $(\mathrm{HR})>20 \%$. It is important to highlight that all those identified as diabetics were considered automatically as $\mathrm{HR}(6)$.

Data were analyzed using the Statistical Software for Social Sciences (SPSS, version 20.0), using descriptive statistics with central tendency and dispersion measures, for numeric variables, and frequency and percentage, for categorical variables. Pearson's chi-square test was used to the analytical statistics of the frequencies distribution between FRS and BMI as well as between FRS and sociodemographic characteristics, considering $\mathrm{p}<0.05$. In order to evaluate the prevalence ratio of BMI over the FRS, a Poisson Regression Test was used.

\section{RESULTS}

Most of the subjects is aged 40-55 (44.2\%), married (75.4\%), from C1-C2-D economic classes (58\%), up to 7 years educated $(73.2 \%)$ and women $(62.3 \%)$. Regarding BMI, it is noteworthy that $88.4 \%$ of employees have some level of overweight (overweight or obese). Obesity prevails among women (51.2\%) and overweight among men $(65.4 \%)$. Regarding the FRS, $81.4 \%$ of women and $51.9 \%$ of men have low risk (Table 1).

Regarding the biochemical characteristics and BP, it can be seen that $58.0 \%$ has increased level of TC, HDL values within the desired standard in $83.3 \%$ of cases. Yet the glucose levels of $43.5 \%$ of workers are in the range of pre-diabetic and $15.9 \%$ in the diabetes range (Table 1).

By analyzing the average values of the indicators that compose the estimate of FRS and the average of risk score, we observed that the factors that had higher scores on the FRS were the mean age $51.32 \pm 10.32$ years and the total cholesterol $211.81 \pm 48.98 \mathrm{mg} / \mathrm{dL}$. It is important to state that $93.5 \%$ of workers had no smoking habit. As regards the systolic pressure, the mean value obtained was $131.67 \pm 17.00 \mathrm{mmHg}$. The average score of $11.09 \pm 6.19$ points represents low risk for myocardial infarction or coronary heart disease within 10 years (Table 2) which is confirmed by the percentage of individuals rated as LR (Table 1 ).
Table 1. Characterization of the sample

\begin{tabular}{|c|c|c|c|}
\hline \multirow[b]{2}{*}{ Variables } & \multicolumn{2}{|c|}{ Gender } & \multirow{2}{*}{$\begin{array}{c}\text { Total }^{*} \\
138(100)\end{array}$} \\
\hline & $\begin{array}{l}\text { Female }^{*} \\
86(62.3)\end{array}$ & $\begin{array}{c}\text { Male }^{\star} \\
52(37.7)\end{array}$ & \\
\hline \multicolumn{4}{|l|}{ Age range } \\
\hline$<40$ years & 14 (16.3) & $11(21.2)$ & $25(18.1)$ \\
\hline $40-55$ years & $41(47.7)$ & 20 (38.5) & $61(44.2)$ \\
\hline$>55$ years & $31(36.0)$ & $21(40.4)$ & $52(37.7)$ \\
\hline \multicolumn{4}{|l|}{ Marital status } \\
\hline Single & $6(7.0)$ & $8(15.4)$ & $14(10.1)$ \\
\hline Married & $65(75.6)$ & $39(75.0)$ & $104(75.4)$ \\
\hline Others & $15(17.4)$ & $5(9.6)$ & $20(14.4)$ \\
\hline \multicolumn{4}{|l|}{ Economic level } \\
\hline B1-B2 & 32 (37.2) & $26(50.0)$ & $58(42.0)$ \\
\hline C1-C2-D & $54(62.8)$ & $26(50.0)$ & $80(58.0)$ \\
\hline \multicolumn{4}{|l|}{ Schooling } \\
\hline Up to 7 years & $64(74.4)$ & 37 (71.2) & 101 (73.2) \\
\hline 8 to 10 years & $9(10.5)$ & $6(11.5)$ & $15(10.9)$ \\
\hline 11 years or more & $13(15.1)$ & $9(17.3)$ & $22(15.9)$ \\
\hline \multicolumn{4}{|l|}{ BMl } \\
\hline Recommended range & $8(09.3)$ & $8(15.4)$ & $16(11.6)$ \\
\hline Overweight & 34 (39.5) & $34(65.4)$ & 68 (49.3) \\
\hline Obesity & $44(51.2)$ & 10 (19.2) & $54(39.1)$ \\
\hline \multicolumn{4}{|l|}{ Total cholesterol } \\
\hline Desirable & 36 (41.9) & 22 (42.3) & $58(42.0)$ \\
\hline Increased & $50(58.1)$ & $30(57.7)$ & $80(58.0)$ \\
\hline \multicolumn{4}{|l|}{ HDL } \\
\hline Desirable & 75 (87.2) & $40(76.9)$ & $115(83.3)$ \\
\hline Decreased & $11(12.8)$ & $12(23.1)$ & $23(16.7)$ \\
\hline \multicolumn{4}{|l|}{ SBP } \\
\hline Recommended range & $34(39.6)$ & $26(50.0)$ & $60(43.5)$ \\
\hline Bordering & 22 (25.6) & 10 (19.2) & 32 (23.2) \\
\hline Hypertension & $30(35.0)$ & $16(30.8)$ & $46(33.3)$ \\
\hline \multicolumn{4}{|l|}{ Glucose } \\
\hline Desirable & $36(41.9)$ & 20 (38.5) & $56(40.6)$ \\
\hline Pre-diabetes & 38 (44.2) & 22 (42.3) & 60 (43.5) \\
\hline Diabetes & $12(14.0)$ & 10 (19.2) & $22(15.9)$ \\
\hline \multicolumn{4}{|l|}{ FRS } \\
\hline Low risk & 70 (81.4) & 27 (51.9) & $97(70.3)$ \\
\hline Intermediate risk & $1(1.2)$ & $12(23.1)$ & $13(9.4)$ \\
\hline High risk & 15 (17.4) & $13(25.0)$ & 28 (20.3) \\
\hline
\end{tabular}

*: frequency (percentage); BMI: body mass index; HDL: high density lipoprotein; SBP: systolic blood pressure; FRS: Framingham Risk Score.

When stratifying the risk of coronary artery disease, according to the FRS, it was observed that $70.3 \%$ of workers has low risk, $8.6 \%$ has intermediate risk and 
22.3\% has high risk When analyzing the risk related to BMI classification, statistical significance was found $(\mathrm{p}=0.035)$ indicating relationship between the variables, while obesity is a preponderant factor in the definition of risk, there are other intervening variables that were not evidenced in this study. Although most of the subjects were rated low risk, it is noteworthy that among subjects with intermediate risk $69.2 \%$ are overweight, since those with high risk in $96.4 \%$ of the patients present weight excess: overweight $(39.3 \%)$ or obese $(57.1 \%)$. Another fact to highlight is the occurrence of high risk in the subject with recommended weight range, which was due to the presence of diabetes mellitus (Table 3 ).

Table 2. Average values in the indicators that composse the Framingham Risk Score

\begin{tabular}{lcc}
\hline FRS variables & Mean value (SD) & Mean score (SD) \\
\hline Age & $51.32(10.32)$ & $4.75(5.51)$ \\
Cholesterol level & $211.81(48.98)$ & $3.70(2.55)$ \\
Smoke $^{\star}[\mathrm{yes} / \mathrm{no}]$ & $9(6.5) / 129(93.5)$ & $0.35(1.51)$ \\
HDL & $49.96(10.97)$ & $0.48(0.94)$ \\
SBP & $131.67(17.00)$ & $1.83(1.88)$ \\
FRS & $11.09(6.19)$ & - \\
\hline
\end{tabular}

*: frequency (percentage); FRS: Framingham Risk Score; HDL: high density lipoprotein; SBP: systolic blood pressure; SD: standard deviation.

Table 3. Relation between BMI and the Framingham Risk Score

\begin{tabular}{lcccc}
\hline \multirow{2}{*}{ BMI } & \multicolumn{3}{c}{ FRS } & \\
\cline { 2 - 4 } & $\begin{array}{c}\text { Low } \\
\text { risk** }^{* *}\end{array}$ & $\begin{array}{c}\text { Intermediate } \\
\text { risk }^{\star *}\end{array}$ & $\begin{array}{c}\text { High } \\
\text { risk }^{* *}\end{array}$ & $\mathbf{p}^{*}$ \\
\hline Recommended range & $12(12.4)$ & $3(23.1)$ & $1(3.6)$ & \\
Overweight & $48(49.5)$ & $9(69.2)$ & $11(39.3)$ & 0.035 \\
Obesity & $37(38.1)$ & $1(7.7)$ & $16(57.1)$ & \\
\hline
\end{tabular}

*: Pearson's chi-square; **: frequency (percentage); FRS: Framingham Risk Score; BMI: body mass index.
When analyzing the prevalence ratio between BMI and FRS, it can be observed that overweight women have $14.7 \%$ greater risk prevalence than those rated as normal BMI. Obese women showed risk prevalence $25 \%$ greater than the eutrophic. This fact was neither observed for the male population, nor in whole sample (Table 4). From Table 5 it comes that, among sociodemographic characteristics, gender and age group are related to FRS, an expected fact, since this factors are component variables of FRS.

Table 5. Relation between sociodemographic characteristics and the Framingham Risk Score

\begin{tabular}{|c|c|c|c|c|}
\hline & \multicolumn{3}{|c|}{ FRS } & \multirow[b]{2}{*}{$\mathbf{p}^{*}$} \\
\hline & $\begin{array}{c}\text { Low } \\
\text { risk }^{\star \star} \\
97(70.3)\end{array}$ & $\begin{array}{c}\text { Intermediate } \\
\text { risk }^{\star \star} \\
13(9.4)\end{array}$ & $\begin{array}{l}\text { High risk }^{\star \star} \\
28(20.3)\end{array}$ & \\
\hline \multicolumn{5}{|l|}{ Gender } \\
\hline Male & 27 (27.7) & 12 (92.3) & $13(46.4)$ & \multirow[t]{2}{*}{$<0.001$} \\
\hline Female & 70 (72.2) & $1(7.7)$ & 15 (53.6) & \\
\hline \multicolumn{5}{|l|}{ Age range } \\
\hline$<40$ years & 20 (20.6) & - & $5(17.9)$ & \multirow{3}{*}{$<0.001$} \\
\hline $40-55$ years & $53(54.6)$ & $3(23.1)$ & $5(17.9)$ & \\
\hline$>55$ years & $24(24.7)$ & $10(76.9)$ & 18 (64.3) & \\
\hline \multicolumn{5}{|l|}{ Marital status } \\
\hline Single & 10 (10.3) & - & $4(14.3)$ & \multirow{3}{*}{0.382} \\
\hline Married & 74 (76.3) & 12 (92.3) & 18 (64.3) & \\
\hline Others & 13 (13.4) & $1(7.7)$ & $6(21.4)$ & \\
\hline \multicolumn{5}{|l|}{ Economic level } \\
\hline B1-B2 & $43(44.3)$ & $4(30.8)$ & $11(39.3)$ & \multirow[t]{2}{*}{0.615} \\
\hline C1-C2-D & $54(55.7)$ & $9(69.2)$ & $17(60.7)$ & \\
\hline \multicolumn{5}{|l|}{ Schooling } \\
\hline Up to 7 years & 69 (71.1) & $11(84.6)$ & $21(75.0)$ & \multirow{3}{*}{0.806} \\
\hline 8 to 10 years & $12(12.4)$ & $1(7.7)$ & $2(7.1)$ & \\
\hline 11 years or more & 16 (16.5) & $1(7.7)$ & $5(17.9)$ & \\
\hline
\end{tabular}

*: Pearson's chi-square; **: frequency (percentage); FRS: Framingham Risk Score.

Table 4. Prevalence ratio of FRS high risk in relation to BMI

\begin{tabular}{lcccccc}
\hline & \multicolumn{2}{c}{ General } & \multicolumn{3}{c}{ Gender } \\
\cline { 2 - 7 } BMI & \multicolumn{2}{c}{ Male } & \multicolumn{2}{c}{ Female } \\
\cline { 2 - 7 } & PR (CI 95\%) & $\mathbf{p}$ & PR (CI 95\%) & $\mathbf{p}$ & PR (CI 95\%) & $\mathbf{p}$ \\
\hline Recommended range & 1 & - & 1 & - & 1 & - \\
Overweight & $1.035(0.86-1.25)$ & 0.719 & $0.961(0.74-1.24)$ & 0.762 & $1.147(1.03-1.27)$ & 0.010 \\
Obesity & $1.052(0.87-1.28)$ & 0.610 & $1.067(0.79-1.44)$ & 0.672 & $1.25(1.13-1.38)$ & $<0.001$ \\
\hline
\end{tabular}

FRS: Framingham Risk Score; BMI: body mass index; PR: prevalence ratio; Cl: confidence interval. 


\section{DISCUSSION}

The results of this cross-sectional study show the prevalence of overweight and obesity among workers classified with intermediate and high cardiovascular risk. Regardless of overweight or obesity present in most of sample, the subjects were often classified with low cardiovascular risk. From the factors considered in the FHS, the ones who obtained the highest scores in the formation of the risk score were age and TC. Variables that may be related because the increase in TC may be associated with increased age, as in this study the subjects had higher mean age (51.32 years) compared with those obtained by workers in other economic sectors, such as studies industrialists $(36.27 \pm 10.21)$ (17) and commercial workers $(27.65 \pm 9.38)$ (18).

This mean age is characteristic of the demographic profile of Brazilian rural workers marked by continuous aging (19). This phenomenon stems from the migration of youth to urban centers, as has also been identified in France (20). This happens due to the migratory flow, which is common in contemporary societies, according to Dasre and cols. (21).

However, in addition to issues related to the logic of the organization and dynamics of production centered on family labor, factors that contribute to male dominance is the aging of the rural population. However, external elements to the family play an important role in the movement of young people to the cities, such as the increasing difficulty of access to basic health and education services (22).

With respect to the average value of $\mathrm{TC}$, it was observed that this was above the recommended as desirable in half the subjects in this study. This result shows resemblance to a survey of urban bus drivers in Teresina (Piauí), in which approximately half of subjects had TC at levels above $200 \mathrm{mg} / \mathrm{dL}$ (10), as well as $39.4 \%$ of 678 drivers, working in alternating shifts in a mining company in Minas Gerais, had increased TC (23). A bi-racial study with women and African-American and white men, found above the recommended cholesterol (> $200 \mathrm{mg} / \mathrm{dL}$ ) among white women (24).

Regarding HDL-c most of the subjects were classified at levels considered adequate $(50.03 \pm 10.96)$. Similar average results were found in a study applied with 2037 subjects (24). It is important to highlight that the small number of smokers $(6.5 \%)$ led to the disregard of this variable in this study.
Although the highest percentage of subjects has presented systolic blood pressure in the proper range, a third of them $(33.1 \%)$ was classified with hypertension. This finding may be associated with the age of the workers, since study in two rural communities identified $42.9 \%$ of hypertensive in 18-94-year-old subjects (25). These findings confirm the scientific evidence that high blood pressure increases progressively with age, being a common condition in people with older age, especially in people over 60 years old (26). The Framingham Heart Study states that the prevalence of hypertension increases from $27.3 \%$, in patients younger than 60 years, to $74.0 \%$ in those aged over 80 years old (27).

In addition to the primary prevention, it is necessary more control and treatment of hypertension, especially in critically ill patients, as shown in a study of medical records of patients from the Cardiology Clinic of Anapolis/GO. The same authors stress the urgency of greater control over risk factors, such as physical inactivity and obesity, in order to avoid the emergence of CVD associated with SAH (28).

This recommendation is based on the influence of overweight in the prevalence of hypertension due to the risk that these changes represent a condition found in $87.8 \%$ of workers. This finding overcomes the data from a study that observed overweight and obesity in $65.5 \%$ of subjects in the hospital area (29) and $40.7 \%$ of farmers in Minnesota, United States (30). It is possible to observe that one of the factors prevalent among hypertensive individuals is the obesity (31).

Regarding BMI, studies show that the prevalence of most chronic diseases are associated with the increase of this anthropometrical measure. In addition, the cardiometabolic risk factors have been affecting both men and women with overweight and obesity (32), with this measure related to increased risk of premature death in subjects with severe obesity or above $35 \mathrm{~kg} / \mathrm{m}^{2}(33)$.

It is worth noting the risk posed by visceral fat and body fat for the development of coronary atherosclerosis, before the presence of comorbidities resulting from cardiovascular diseases (34). Thus, the Framingham score, for its ability to anticipate the identification of individuals at risk of developing cardiovascular events, is an important method for the primary prevention. Preventive interventions should be proposed and are indispensable in order to prevent the occurrence of any event.

Regarding the groups, no significant differences were observed between the clinical variables. According to 
the Framingham risk score, the average value found was 10.93 points, featuring intermediate risk of coronary events in 10 years. The results found in this study show that $22.3 \%$ of the subjects are at high risk of developing coronary event. Unlike the study of 309,955 workers in different economic sectors in Spain, with an average age of 36.5 years, in which $5.9 \%$ of the subjects were classified with high risk and $0.9 \%$ with moderate risk, those classified with high cardiovascular risk $7.6 \%$ were men and $1.7 \%$ were women, with a higher occurrence in agricultural (11.3\%) and construction workers $(8.2 \%)$, when compared to the industrial and services sector (35).

Finally, it is worth noting the presence of abnormal glucose $(59.0 \%)$ with diabetic (15.8\%) and pre-diabetic patients $(43.2 \%)$ in the group assessed, highlighting the importance of primary actions that may reverse health complications through the assessment of cardiovascular risk in rural workers, using the Framingham risk Score, and stratify its distribution according to the classification of body mass index.

We considered the high number of diabetics in the sample was due to several factors, such as the advanced age of the individuals, the great number of overweight subjects and the fact that they referred not having regular attendance for this marker. Another point to be highlighted is the fact that men does not present risk increase as BMI increase. This fact points to weakness of BMI for part of this group, which could have been influenced by factors as lean mass increasing, what is not discriminated by BMI. Thus, we are sendend towards further investigations related to body composition and cardiovascular risk addressing the specifities of this population, especially regarding to the high average age.

The subjects of the study have a labor fairly active, mainly the men, which are more involved in heavy farm activities. Thus, men BMI might be biased, which could be explained by the overweight caused by lean body mass instead of fat body mass, since BMI does not tell which kind of body mass. This hypothesis could be investigated in future researches, using different anthropometric variables.

This study showed the presence of low risk for coronary events in the study population, estimated by the Framingham Risk Score. The influence of BMI on increasing cardiovascular risk was observed in the women workers. However, this fact was not identified in men. Neverthless, these results show the importance of this variable when implementing actions that can stimulate healthier lifestyles, especially when addressed to a population with limited access to health care networks, as in the case of rural workers.

Acknowledgements: workers and organizers related to research subjects who have committed and provided their time to participate.

Financial support: this work was supported by Secretaria de Desenvolvimento Econômico, Ciência e Tecnologia do Estado do Rio Grande do Sul, by Universidade de Santa Cruz do Sul, by Fundação de Amparo à Pesquisa do Estado do Rio Grande do Sul (Fapergs) and the Conselho Nacional de Desenvolvimento Científico e Tecnológico (CNPq).

Disclosure: no potential conflict of interest relevant to this article was reported.

\section{REFERENCES}

1. Organização Mundial de Saúde. Estadísticas sanitarias mundiales. OMS; 2011.

2. Cesarino EJ, Vituzzo ALG, Sampaio JMC, Ferreira DAS, Pires HAF, Souza L. Assessment of cardiovascular risk of patients with arterial hypertension of a public health unit. Einstein. 2012;10(1):33-8.

3. Cesarino CB, Borges PP, Ribeiro RCHM, Ribeiro DF, Kusumota L. Avaliação do risco cardiovascular de pacientes renais crônicos segundo critérios de Framingham. Acta Paul Enferm. 2013;26(1):101-7.

4. Sociedade Brasileira de Cardiologia/Sociedade Brasileira de Hipertensão/Sociedade Brasileira de Nefrologia. VI Diretrizes Brasileiras de Hipertensão. Arq Bras Cardiol. 2010;95(supl. 1):1-51.

5. Wunsch VF. Perfil epidemiológico dos trabalhadores. Rev Bras MedicinaTrab. 2004;2(2):103-17.

6. Huang JH, Huang SL, Li RH, Wang LH, Chen YL, Tang FC. Effects of nutrition and exercise health behaviors on predicted risk of cardiovascular disease among workers with different body mass index levels. Int J Environt Res Public Health. 2014;11(5):4664-75.

7. Moreira JPL, Oliveira BLCA, Muzi CD, Cunha CLF, Brito AS, Luiz RR. A saúde dos trabalhadores da atividade rural no Brasil. Cad Saúde Pública. 2015;31(8):1698-708.

8. Dias EC. Condições de vida, trabalho, saúde e doença dos trabalhadores rurais no Brasil. Saúde do Trabalhador Rural RENAST. 2006.

9. Oliveira DS, Tannus LRM, Matheus ASM, Corrêa FH, Cobas R, Cunha EF, et al. Avaliação do risco cardiovascular segundo os critérios de Framingham em pacientes com diabetes tipo II. Arq Bras Endocrinol Metab. 2007;51(2):268-74.

10. Landim MBP, Victor EG. Escore de Framingham em Motoristas de Transporte Coletivo Urbano de Teresina, Piauí. Arq Bras Cardiol. 2006;87(3):315-20.

11. Ministério da Saúde. Protocolo clínico e diretrizes terapêuticas: dislipidemias em pacientes de alto risco de desenvolver eventos cardiovasculares; 2002.

12. 12. Bertê AMA, Lemos BO, Testa G, Zanella MAR, Oliveira SB. Perfil socioeconômico - COREDE Vale do Rio Pardo. Boletim Geográfico do Rio Grande do Sul. 2016;26:984-1024.

13. ABEP. Associação Brasileira de Empresas de Pesquisas. Critério de Classificação Econômica Brasil. 2014. Available from: http:// www.abep.org/criterio-brasil. Accessed on: 25 Oct. 2016.

14. VI Diretriz Brasileira de Hipertensão. Rev Bras Hipertens. 2010;17(1):7-10. 
15. American Diabetes Association. Standards of Medical Care in Diabetes. ADA. 2013.

16. Sociedade Brasileira de Cardiologia. III Diretrizes Brasileiras sobre Dislipidemias e Diretriz de Prevenção da Aterosclerose. Arq Bras Cardiol. 2001;77(supl. III):48.

17. Swarowsky I. A obesidade e os riscos à saúde de trabalhadores de uma indústria de Santa Cruz do Sul [dissertação]. Rio Grande do Sul. Universidade de Santa Cruz do Sul; 2012.

18. Pohl HH, Reckziegel MB, Reuter EM, Galliano LM, Corbellini VA, Stein MJ. Perfil de saúde dos trabalhadores do comércio: um estudo relacionado à aptidão física. Rev Bras Pesq Saúde. 2013;15(1):17-24.

19. Abramovay R (coord.). Os impasses da sucessão hereditária na agricultura familiar. Florianópolis. EPAGRI; NEAD/Ministério do Desenvolvimento Agrário; 2001.

20. Champagne P. Élargissement de l'espace social et crise de I'identité paysanne, Cahier d'Éco Soc Rur. 1986; déc.(3):73-89.

21. Dasre A, Kersuzan C, Caillot M, Bergouignan C. Sélectivité migratoire des populations selon leur âge et concentrations socio-spatiales. Espace Pop Soc. 2009;1:67-84.

22. Anderson JSN, Schneider S. Brazilian Demographic Transition and the Strategic Role of Youth. Espace Populations Societies. 2014;2-3.

23. Alves ME. Fatores de risco nutricionais, comportamentais, clínicos e bioquímicos para doenças cardiovasculares em trabalhadores de turnos alternantes da região dos inconfidentes, Minas Gerais, Brasil. 2012. 116f. Dissertação (Programa de PósGraduação em Ciências Biológicas) - Universidade Federal de Ouro Preto, Ouro Preto, 2012.

24. Barreira TV, Staiano AE, Harrington DM, Heymsfield SB, Smith $\mathrm{SR}$, Bouchard C, et al. Anthropometric correlates of total body fat, abdominal adiposity, and cardiovascular disease risk factors in a biracial sample of men and women. Mayo Clin Proc. 2012;87(5):452-60.
25. Matozinhos FP, Mendes LL, Oliveira AGC, Velasquez-Melendez G. Fatores associados à hipertensão arterial em populações rurais. Rev Min Enferm. 2011;15(3):333-47.

26. Pimenta $\mathrm{E}$, Oparil S. Management of hypertension in the elderly. Nat Rev Cardiol. 2012;9(5):286-96.

27. Lloyd-Jones DM, Evans JC, Levy D. Hypertension in adults across the age spectrum: current outcomes and control in the community. JAMA. 2005;294:466-72.

28. Tacon KC, Pereira AS, Santos HCO, Castro EC, Amaral WN. Perfil epidemiológico da hipertensão arterial sistêmica em pacientes atendidos em uma instituição de ensino superior. Rev Bras Clin Med. 2012;10(3):189-93.

29. Cavagioni L, Pierin AMG. Risco cardiovascular em profissionais de saúde de serviços de atendimento hospitalar. Esc Enferm. 2012;46(2):395-403.

30. Prokosch AJ, Dalleck LC, Pettitt RW. Cardiac Risk Factors between Farmers and Non-Farmers. JEPonline. 2011;14(3):91-100.

31. Radovanovic CAT, Santos LA, Carvalho MDB, Marcon SS. Hipertensão arterial e outros fatores de risco associados às doenças cardiovasculares em adultos. Rev Latino-Am Enfermagem. 2014;22(4):547-53.

32. Schienkiewitz A, Gert BMM, Scheidt-Nave C. Comorbidity of overweight and obesity in a nationally representative sample of German adults aged 18-79 years. BMC Public Health. 2012;12(1):658.

33. Schneider HJ, Friedrich N, Klotsche J, Pieper L, Nauck M, John $U$, et al. The predictive value of different measures of obesity for incident cardiovascular events and mortality. J Clin Endocrinol Metab. 2010;95(4):1777-85.

34. Lee SY, Chang HJ, Sung J, Kim KJ, Shin S, Cho IJ, et al. The impact of obesity on subclinical coronary atherosclerosis according to the risk of cardiovascular disease. Obesity. 2014;22(7):1762-68.

35. Chaparro MAS, Bonacho EC, Quintela AG, Cabrera M, Sáinz JC, Labander $\mathrm{CF}$, et al. High cardiovascular risk in Spanish workers. Nut Met Card Dis. 2011;21(4):231-36. 